\title{
Tradition as Renewal: An Old Catholic Perspective on Renewal in Church and Theology
}

\author{
Peter Ben SMit ${ }^{*}$
}

This paper argues that precisely by focusing on the continuation of tradition, Old Catholic theology is able to arrive at theological renewal, especially in an intercultural manner and in ecumenical dialogue. As a case study, this paper considers the recent dialogue between the Union of Utrecht of Old Catholic Church and the Mar Thoma Syrian Church.

Keywords: renewal, mission, tradition, ecumenism, old Catholicism, Mar Thoma, intercultural theology, church history

\section{Introduction}

"Oh, are you part of the Society of Pius X, then?" Old Catholics, members of the Old Catholic Churches of the Union of Utrecht, are sometimes confronted with remarks such as this upon indicating that they are members of an Old Catholic Church. Confusion reigns, then, given that Old Catholics often take pride in the fact that they are not traditionalists, but, on the contrary, seek to pass on the living tradition of the Church in lively dialogue with today's society. The cause of the confusion is the notion "old" in the name "Old Catholic." Here, this notion will be unpacked in relation to the question of ecclesial and (therefore) theological renewal. In particular, it will be argued that the notion of "tradition" in Old Catholic theology implies renewal rather than conservatism due to a dynamic, ecumenical return to the sources, in a process that can be described along the lines of intercultural theology. In doing so, first, a brief sketch will be given of the notion of "tradition" as it was developed in the $19^{\text {th }}$ century Old Catholic movement (a movement that included earlier traditions, notably the tradition of the Church of Utrecht with its strong Augustinian emphasis) ${ }^{1}$ will be discussed, then attention will be given to the discussion concerning tradition and its

\footnotetext{
* Peter-Ben Smit, PhD, extraordinary professor of Ancient Catholic Church Structures and the History and Doctrine of Old Catholicism at Utrecht University, assistant professor of New Testament at the Faculty of Theology of VU University Amsterdam, associate researcher at the Faculty of Theology of the University of Pretoria, assistant rector of the Old Catholic parish of Amsterdam; email: p.b.a.smit@uu.nl.

1 See, e.g., the account offered by Dick J. Schoon, Van bisschoppelijke Cleresie tot OudKatholieke Kerk. Bijdrage tot de geschiedenis van het katholicisme in Nederland in de 19 e eeuw, Nijmegen 2004.
} 
development in the $20^{\text {th }}$ century, in which Old Catholic - Orthodox dialogue will figure prominently, and finally, using the case study of a recent ecumenical dialogue of the Old Catholic Churches of the Union of Utrecht with the Mar Thoma Syrian Church of Malabar (conducted between 2011-2014), ${ }^{2}$ it will be argued how an Old Catholic understanding of "tradition," ecumenical and ecumenically inspired as it is, has a strong intercultural character as well.

\section{Protest, Renewal, and Rapprochement: Tradition in $19^{\text {th }}$ Century Old Catholicism}

The name "Old Catholic" refers to the catholicity of the early Church. ${ }^{3}$ The notion "early Church", however, is often considered to be rather general, if not outright vague. More interesting than the precise period that is meant by "early Church" in Old Catholic theology, is the question what the function of the appeal to the early Church is in Old Catholic tradition. While the period meant is, generally speaking, the first millennium (or the period until the "great schism" between East and West), or the age of the seven ecumenical councils, ${ }^{4}$ the function of the appeal to the church, its faith and order, of this era was a threefold one in the 19th century. The context of the appeal was provided by

2 On which see: Peter-Ben Smit, "Ecumenical Dialogue as Intercultural Encounter. The Dialogue Between the Mar Thoma Syrian Church and the Old Catholic Churches of the Union of Utrecht as an Example of Intercultural Theological Dialogue" forthcoming in: Exchange (2015). For the statements of the dialogue, see the "Santhigiri Statement" as it was published in the Internationale Kirchliche Zeitschrift, 102 (2012), p. 315-320. See also: http:// www.utrechter-union.org/fman/261.pdf, accessed December 1, 2014, the Hippolytus Statement 2013, see: http://www.utrechter-union.org/fman/260.pdf, accessed December 1, 2014 and the Munnar Statment, see: http://www.utrechter-union.org/fman/259.pdf , accessed December 1, 2014.

3 See: Urs von Arx, "Was macht die Kirche katholisch? Perspektiven einer christkatholischen Antwort" in: Wolfgang W. Müller (ed.), Katholizität - Eine ökumenische Chance. Schriften Ökumenisches Institute Luzern 4, Zürich 2006, p. 147-186.

4 See, e.g, the programm of the first "Katholikenkongress" (Munich, 1871) in: Johann Friedrich von Schulte, Der Altkatholizismus, Aalen 2002, reprint oft he edition published in Giessen, 1887, p. 22-24; see further: Urs Küry, Die Altkatholische Kirche ihre Geschichte, ihre Lehre, ihr Anliegen. Die Kirchen der Welt 3, revised by Christian Oeyen, Stuttgart ${ }^{3} 1982$, p. 66-67. See on this topic also: Andreas Rinkel, "Wort Gottes und Tradition in der altkatholischen Kirche unter besonderer Berücksichtigung der Utrechter Konvention" in: Internationale Kirchliche Zeitschrift 29 (1939), p. 51-61, Matthias Ring. "Ad pristinam normam patrum. Anmerkungen zum alt-katholischen Reformparadigma" in: Angela Berlis, Klaus-Dieter Gerth (eds.), Christus spes. Liturgie und Glaube im ökumenischen Kontext, Frankfurt 1994, p. 255-264; Jan Visser, "Die Alte Kirche als hermeneutisches Prinzip" in: IKZ 86 (1996), p. 45-64; Ch. Oeyen, "Die Alte Kirche als Norm nach Döllinger und seiner Schule" in: Internationale Kirchliche Zeitschrift 86 (1996), p. 26-44; U. Küry, "Der canon fidei der alten Kirche und wir" in: IKZ 52 (1962), p. 86-99. 
the ecclesiological and dogmatic developments in the Roman Catholic Church, resulting in the dogmatic decisions of the First Vatican Council concerning papal infallibility and universal jurisdiction (pastor aeternus, 18 July 1870). ${ }^{5}$ The function of the appeal was to provide an alternative for these innovations (hence the emphasis on "Old" Catholic, as in "original" or "authentic" Catholic). In this context, the appeal to the early Church has three distinct aspects. In the first place, it served as the basis for the theological protest against the decisions of the First Vatican Council, as they went against the faith and order of the early Church. Second, it was seen as the basis for attempts to achieve ecclesial rapprochement between hitherto divided churches (in particular the Orthodox and Anglican Churches). Third, it was seen as the main source for ecclesial renewal and the rediscovery of the missionary vigour of the church. ${ }^{6}$

\section{Tradition, Scripture, and Renewal in the $20^{\text {th }}$ Century}

In the $20^{\text {th }}$ century, the discussion on tradition, the appeal to the early Church, its relation to Scripture, and, above all, the relation of the Church's tradition to the renewal of the life of the Church began to be more prominent again towards the end of the century, when the discussion surrounding the ordination of women was at its apex. It was clear for Old Catholics that any decision concerning this matter needed to be taken on the basis of the faith of the early church and in consultation with their most important ecumenical partners, Anglicans and, especially, the Orthodox (see below). Still, what sort of understanding of tradition would be required to do justice both to the faith and order of the early Church and to the questions asked by today's Church with regard to a renewal of the ministry of the Church and the ordained ministry within it? In order to arrive at a satisfactory sketch of this discussion, ${ }^{7}$ it is necessary to start a little earlier, with an observation of the Old Catholic theologian Kurt Stalder, who, in 1968 noted that reflection on the question of Scripture and Tradition had not been particularly prominent in Old Catholicism since the formation of the Union of Utrecht in $1889 .^{8}$ The first

5 On the Old Catholic movement in this period in general, see, e.g. Angela Berlis, Frauen im Prozeß der Kirchwerdung: Eine historisch-theologische Studie zur Anfangsphase des deutschen Altkatholizismus (1850-1890), Frankfurt 1998, p. 86-232.

6 See: M. Ring, „Ad pristinam normam“; Andreas Krebs, “"... den blühendsten Zustand der Kirche wieder herbeizuführen». Papstkritik und Alte Kirche bei Joseph Hubert Reinkens" in: IKZ 101 (2011), p. 101-115.

For this sketch, see also P.-B. Smit, Old Catholic and Philippine Independent Ecclesiologies in History. The Catholic Church in Every Place. Brill's Series in Church History 52,Leiden 2011, p. 408-414, the text of which agrees with what follows here.

8 See U. Küry, "Die Internationalen altkatholischen Theologentagungen von 1950 bis 1971" in: Internationale Kirchliche Zeitschrift 67 (1977), p. 106-124, 140-184; Internatio- 
extensive discussion took place between Arnold Gilg and Andreas Rinkel at the 1938 Old Catholics' Congress in Zürich. ${ }^{9}$ Before this, it seems that Old Catholic understanding of Scripture and Tradition was adequately expressed in the 1889 Declaration of Utrecht and the ninth thesis of the 1874 Bonn Conference on Church Union, which stated the following:

Während die Hl. Schrift anerkanntermaßen die primäre Regel des Glauben ist, erkennen wir an, daß die echte Tradition, d.h. die ununterbrochene, teils mündliche, teils schriftliche Überlieferung der von Christus und den Aposteln zuerst vorgetragenen Lehre eine autoritative (gottgewollte) Erkenntnisquelle für alle aufeinander folgenden Generationen von Christen ist. Diese Tradition wird teils erkannt aus dem Consensus der großen in historischer Kontinuität mit der ursprünglichen Kirche stehenden Kirchenkörper, teils wird sie auf wissenschaftlichem Wege ermittelt aus den schriftlichen Denkmälern aller Jahrhunderte. $^{10}$

After the Second World War, the theme was briefly taken up at the 1951 theologians' conference in Bonn in the context of an exchange of views between Dutch and Swiss Old Catholics on the influence of the dialectic theology on the Swiss Old Catholic Church, but no agreed statement was made. ${ }^{11}$

Renewed discussion of the theme of Scripture in Tradition in Old Catholicism took place after the Second Vatican Council, which had outlined a new understanding of the issue in its constitution on revelation (Dei Verbum), thus inviting an Old Catholic response. Hence, Dei Verbum

nale Kirchliche Zeitschrift 68 (1978), p. 83-122, "In einem weit ausholenden Korreferat zeigt Stalder auf, dass in der altkatholischen Kirche die Frage «Schrift und Tradition» zunächst nicht speziell zur Diskussion gestellt wird. Man verbleibt mit der Konzilsmehrheit von 1870 auf dem Boden des Tridentinums. Man versteht, wie anhand der altkatholischen Katechismen und von Verlautbarungen der Altkatholiken-Kongresse gezeigt wird, die Offenbarung als Mitteilung von göttlichen Wahrheiten und stellt die Lehrtradition der Kirche mehr oder weniger deutlich an die Seite der Hl. Schrift (9. These der Bonner Unionskonferenz von 1874). Der holländische Katechismus zeigt insofern eine neue Sicht, als er die Offenbarung als Begegnung mit dem rettenden Tun Gottes versteht. Zu einer tieferen Auseinandersetzung kommt es erst am Altkatholiken-Kongress in Zürich von 1938."

9 See: P.-B. Smit, "An Old Catholic View of Scripture and Tradition: A Short Study of a Theological Organism” in: Internationale Kirchliche Zeitschrift 97 (2007), p. 106-123.

10 See: U. Küry, Die altkatholische Kirche, p. 463. In 1931, this thesis was used by the Old Catholic delegation to outline the Old Catholic understanding of Scripture at the conference in Bonn leading to the Bonn agreement.

11 See: U. Küry, "Die Internationalen altkatholischen”, p. 151. Rinkel restated his views of 1938 in 1965; see: Andreas Rinkel, "Das altkatholische Bekenntnis" in: Internationale Kirchliche Zeitschrift 55 (1965), p. 201-216, 205-208. 
was discussed at the International Old Catholic Theologians' Conference in Zürich in $1968 .{ }^{12}$

It seems that the first representative Old Catholic statement on tradition in the sense of an agreed statement can be found in the documentation of the Old Catholic-Orthodox dialogue. This dialogue agreed the following in 1975:

4. [The] supernatural revelation in Christ is communicated in the Tradition of the Holy Apostles, which was handed on in written form in the Scriptures inspired by God and in oral form by the living voice of the Church. The oral tradition is preserved, on the one hand, in the Creed and other definitions and canons of the seven Ecumenical Councils and local synods, in the writings of the Holy Fathers and in the holy liturgy and generally in the Church's liturgical practice, and, on the other hand, finds expression in the continued official teaching of the Church. 5. Scripture and tradition are not different expressions of the divine revelation but distinct ways of expressing one and the same Apostolic Tradition. Nor does any question arise, therefore, of the precedence of one over the other: both have the same force in relation to true religion` (Basil the Great, Spir. 272 - PG 32.188). «Scripture is understood within the tradition, but the tradition preserves its purity and the criterion of its truth through Scripture and from the content of Scripture.) (Inter-Orthodox Preparatory Commission for the Holy and Great Synod, $16^{\text {th }}$ to $28^{\text {th }}$ July, Chambésy 1973, p. 110). The Apostolic Tradition is preserved and handed on unadulterated by the Church in the Holy Spirit. ${ }^{13}$

Another significant statement is made in the agreed statement on ecclesiology of the same dialogue, which was agreed in 1981:

A continuous task of the Church is the interpretation of Holy Scripture. Holy Scripture does not stand above the Church; it came into being in it. As the Church lives in the light of the witness of Holy

12 See U. Küry, “Die Internationalen altkatholischen”, p. 83-89. See for Küry's own view: "Der canon fidei der Alten Kirche und wir" in: Internationale Kirchliche Zeitschrift 52 (1962), p. 86-99, Küry places a very strong emphasis on the primacy of Scripture over all other tradition. By way of contrast, Marinus Kok published in the same volume of the Internationale Kirchliche Zeitschrift, which was dedicated to his former teacher Rinkel, an essay entitled, "Vinzenz von Lerinum und sein Commonitorium" in: Internationale Kirchliche Zeitschrift 52 (1962), p. 75-85, in which he describes a much more organic relationship between Scripture and Tradition: Scripture is a particularly clear fixation of and witness to Tradition, but not the entirety of revealed Tradition.

13 U. von Arx (ed.), Koinonia auf altkirchlicher Basis. Deutsche Gesamtausgabe der gemeinsamen Texte des orthodox-altkatholischen Dialogs 1975-1987 mit französischer und englischer Übersetzung. Beiheft Internationale Kirchliche Zeitschrift 79, Bern 1989, p. 174-175. 
Revelation, so Holy Scripture is also understood and interpreted in connection with living tradition in the Church and with its decisions regarding issues of faith. That is why only that doctrine is true - beyond the difficulty of expression bound to specific time and conditioned by language - that agrees in its essence with Holy Scripture and holy Tradition. In expressing its authority in dogmatic decisions, the Church always rests on both, that is on Holy Scripture and holy Tradition, by preserving the testimony of both and deepening their understanding. ${ }^{14}$

Thus, attempting to find a formulation of the common faith based on the witness of the early church, the Old Catholic-Orthodox dialogue evidenced the significance of tradition in Old Catholicism. The joint statements just quoted can be viewed as a conclusion of a second period in the development of an Old Catholic view of tradition, in which specifically the relationship between Scripture and Tradition was considered (a first phase used the notion of faithfulness to the church's Tradition as a means of articulating the protest against Pastor Aeternus).

However, as Herwig Aldenhoven already noted in his introduction to the publication of all the joint statements in 1987, the joint commission had restricted itself to finding common ground on the basis of the early church (and in terms of theological principles), and had not set itself the task of translating the faith of the early church for today's context. ${ }^{15}$ Both according to the broader sensus fidelium as well as according to most, if not all, Old Catholic theologians there was a consensus at the end of the 1970s and the early 1980s that further reflection on the faith of the early church as a theological principle was needed, as the (unqualified) appeal to the undivided church of the first millennium was felt to be less and less comprehensible and acceptable. ${ }^{16}$ This, at least, was stated by the 1981 International Old Catholic Theologians' Conference, which described the church as follows:

Die Kirche muss also ein fortwährender Prozess der Wahrheits- und Entscheidungsfindung und des gemeinsamen Handelns sein, an dem alle beteiligt sind. Diese Beteiligung aller zu ermöglichen ist die Aufgabe des Amtes in Apostolischer Sukzession. Die Altkatholischen Kirchen der Utrechter Union glauben, dass sie damit die Tradition (Leben

\footnotetext{
14 U. von Arx (ed.), Koinonia auf altkirchlicher, p. 194-195.

15 See: Herwig Aldenhoven, "Charakter, Bedeutung und Ziel der Dialogtexte“ in: U. von Arx (ed.), Koinonia auf altkirchlicher, p. 27-44, 33-34.

16 See: "Erklärung der Internationalen Altkatholischen Theologentagung 1981" in: Internationale Kirchliche Zeitschrift 73 (1983), p. 65-69: "Die immer wieder erfolgende Berufung altkatholischer Kirchen und Theologen auf die Tradition der «ungeteilten Kirche des 1. Jahrhunderts» wird heute oft als unbegreiflich und unmöglich betrachtet.”
} 
und Aufgabe) der ungeteilten Kirche des 1. Jahrtausends in einer den heutigen Problemen angemessenen Weise weiterführen. ${ }^{17}$

In this context, the first thesis of the International Old Catholic Theologians' Conference of 1984 is also significant, as it refers to the way one has to treat the tradition of the early church with respect to the possibility of the ordination of women. It notes that the objections of this tradition to the ordination of women were of a non-theological kind, and may be seen as outdated. ${ }^{18}$ The awareness that more attention was needed to find ways in which the church could receive and interpret tradition was also a major concern of the theologians' conference that was specifically concerned with the results of the Old Catholic-Orthodox dialogue (1988). ${ }^{19}$

The theme of (Scripture and) Tradition was taken up once more in 1995 by a further theologians' conference. ${ }^{20}$ This conference issued a declaration including the following section on the appeal to the early Church: ${ }^{21}$

17 Internationale Altkatholische Theologenkonferenz, "Erklärung der Internationalen Altkatholischen Theologentagung 1981" in: Internationale Kirchliche Zeitschrift 73 (1983), p. 65-69. The Anglican-Old Catholic theologians' conference of one year prior mainly reemphasized the importance of the tradition of the early church. See: Anglican/Old Catholic Theological Conference Trier, April 14-18, 1980, "Joint Statement" in: One in Christ 16 (1980), p. 375-377.

18 See Edgar Nickel, "Für eine reichere Entfaltung des apostolischen Amtes im Blick auf die Ergänzung von Mann und Frau. 24. Internationale Altkatholische Theologenkonfernz vom 27. August bis 1. September 1984" in: Internationale Kirchliche Zeitschrift 75 (1985), p. 65-70.

19 See the statement of the international Old Catholic theologians' conference of 1988, as published by Roland Lauber, "Bericht über die 27. Internationale Altkatholische Theologenkonferenz in Innsbruck vom 5. bis 10. September 1988” in: Internationale Kirchliche Zeitschrift 79 (1989), p. 29-79, see esp. the issues mentioned on 78. See in this context also: Jan Visser, "Kirchenstruktur und Glaubensvermittlung" in: Internationale Kirchliche Zeitschrift 79 (1989), p. 174-191, who argues that Old Catholic ecclesiology has hermeneutical consequences.

20 This conference addressed an issue that had surfaced at the 1993 International Theologians Conference, namely the differing understandings about the church's dealing with tradition within the Union of Utrecht. See: E. Nickel, "Die Berufung auf die Alte Kirche als Hilfe auf dem Weg in die Zukunft. Bericht über die 32. Internationale Altkatholische Theologenkonferenz vom 4.-9. September 1995 in Friedewald" in: Internationale Kirchliche Zeitschrift 86 (1996), p. 1-15; see also Daniel Konrad, "Dimensionen der Utrechter Union. 31. Internationale Altkatholische Theologenkonferenz in Malvern bei Philadelphia, 23.-27. August 1993" in: Internationale Kirchliche Zeitschrift 84 (1994), p. 7-19.

21 The various contributions to the conference are paraphrased by E. Nickel; two of the conference's papers were published: Christian Oeyen, "Die Alte Kirche als Norm nach Döllinger und seiner Schule" in: Internationale Kirchliche Zeitschrift 86 (1996), p. 26-44; Jan Visser, "Die Alte Kirche als hermeneutisches Prinzip" in: Internationale Kirchliche Zeitschrift 86 (1996), p. 45-64. All speakers at the conference emphasized the character of the appeal to 
Die Internationale Altkatholische Theologenkonferenz ist zu der Feststellung gekommen, dass die Berufung auf die Alte Kirche sich nicht allein auf Glaubensinhalte bezieht, sondern auch auf die Art und Weise, wie man in Fragen des kirchlichen Lebens zu einer Übereinstimmung kommt. Dieser Prozess zur Bewahrung kirchlicher Gemeinschaft war gekennzeichnet von synodalen und konziliaren Beratungen. Er war in der Alten Kirche eingebettet in Einheit und Vielfalt. Diese beiden Prinzipien der "Synodalität" und der „Einheit in Vielfalt" stützen und ergänzen sich gegenseitig. ${ }^{22}$

Thus, this conference aimed in its conclusion at recovering a particular aspect of the recourse to the early Church, namely the synodal and conciliar style of processes of discernment. In this way, the question of the appeal to the early Church is placed in a double hermeneutical relationship: the hermeneutical relationships of various interpreters with each other (emphasized by the 1995 conference) and the hermeneutical relationship with the 'Tradition and traditions.' Little new is said about the principle of the appeal to the faith and order of the early Church as such; mainly additional hermeneutical awareness is raised. As Oeyen stated, Rinkel's view of things from 1938 is still valid:

Wir sind überzeugt, dass nur ein treues Festhalten an diesem Standpunkt unserer Arbeit in der ökumenischen Bewegung Bedeutung verleihen kann und überhaupt die einzige, aber zugleich auch die zwingenste Daseinsberechtigung unserer Kirche ist. So bleibt die letzte Folgerung dieses Standpunktes, die ich an letzter Stelle als die am schwersten uns obliegenden Pflicht nenne, nämlich das treue Studium unserer eigenen, durch und durch kirchlichen katholischen Theologie (...). Unsere Theologie hat den ganzen Reichtum der ganzen Schrift, wie er uns von der katholischen Tradition überliefert worden ist, immer aufs neue zu entfalten, und sie darf dieses tun auf streng wissenschaftlichem Wege und mit gläubigem Herzen. Unsere Theologie hat weder Grund noch Pflicht, sich, sei es von zeitgeschichtlichen Geistesströmungen und ihren von diesen berauschten Anhängern, ins Schlepptau nehmen zu lassen. Unsere Theologie hat sich immer nur durch die Tradition hindurch auf die Schrift zu besinnen und auf diesem Wege den ganzen katholischen Glauben zu verkündigen. ${ }^{23}$

the early church in the various brands of Old Catholicism as the appeal to an ideal or norm, an ideal in as far as the faith of the early church, which is the criterion (norm) for the contemporary faith, can never be fully pinned down, but is always something to be rediscovered.

22 E. Nickel, "Die Berufung auf”, p. 15.

23 Andreas Rinkel, "Wort Gottes und Tradition in der altkatholischen Kirche unter besonderer Berücksichtigung der Utrechter Konvention" in: Internationale Kirchliche Zeitschrift 29 (1939), p. 51-61, quoted by: C. Oeyen, "Die alte Kirche”, p. 44. 
This perspective, which is in agreement with the consensus of the International Old Catholic Theologians' Conference of 1995, is also confirmed by the findings of the Old Catholic-Orthodox consultation on the ordination of women of 1996. In this consultation, the question of tradition, as was already indicated, was of paramount importance. Meeting twice in 1996 with the blessing of the Ecumenical Patriarch and the Archbishop of Utrecht, under the patronage of Metropolitan Damaskinos of Switzerland and Bishop Hans Gerny of the Old Catholic Church of Switzerland, ${ }^{24}$ it presents Old Catholic (and Orthodox) self-understanding and theological method in an exemplary way in its (joint) conclusions, which justifies their quotation in full here:

In Treue zum Schatz der Überlieferung verstehen wir diese als einen vom Geist Gottes gewirkten Prozess dynamischer Aktualisierung des Glaubens für das Leben und das Zeugnis der Kirche in ihrer jeweiligen Gegenwart. Das wirft Fragen eines angemessenen Umgangs mit der Überlieferung auf (hermeneutische Frage).

So stellen wir fest, dass die Kirchen heute zu Recht die Würde der Laien und insbesondere der Frauen betonen und es für wichtig halten, dass sie einen angemessenen Platz im Leben und in der Sendung der Kirche einnehmen. Das entspricht dem Umstand, dass die verschiedenen Aufgaben in der Kirche ihre Verankerung in der Zuordnung der Glieder im Leib Christi haben (1 Kor 12).

Im Sinn des obengenannten Verständnisses der Überlieferung haben wir auch die historischen Gegebenheiten, die als Begründungen für den «männlichen Charakter» des Priestertums vorgebracht werden, untersucht: Das männliche Geschlecht des menschgewordenen Sohnes Gottes, Jesu Christi Auswahl von Männern in den Kreis der Zwölf, die ausschliessliche Einsetzung von Männern in den priesterlichen Dienst der Kirche, wie auch die damit zusammenhängenden Argumentationen mit Typologien (z.B. Adam-Christus, Eva-Maria) und mit Bildbzw. Repräsentationsdenken.

Wir sind dabei zur gemeinsamen Überzeugung gekommen, dass keine zwingenden dogmatisch-theologischen Gründe vorliegen, dass Frauen nicht zum priesterlichen Dienst geweiht werden. Bestimmend für unsere Überlegungen war dabei die soteriologische Dimension der Kirche

24 In the context of the discussion about the ordination of women, this was the only largescale ecumenical consultation that took place: the Church of England had made its view clear with its 1992 decision to ordain women to the priesthood, and the Roman Catholic Church issued Ordinatio Sacerdotalis in 1994, thus rendering dialogue superfluous as well. See: U. von Arx, "Die Debatte über die Frauenordination in den Altkatholischen Kirchen der Utrechter Union“ in: Denise Buser, Adrian Loretan (eds.), Gleichstellung der Geschlechter und die Kirchen. Ein Beitrag zu menschenrechtlichen und ökumenischen Diskussion, Freiburg i.Ue. 1999, p. 165-211. 
und ihrer Sendung: Das Heil der Menschen und der ganzen Schöpfung in Jesus Christus, in dem sich die neue Schöpfung vollzieht. Im Besonderen war die in der Alten Kirche herrschende Überzeugung wegweisend: Nur was angenommen und mit Gott geeint wurde, ist gerettet. Es ist die ganze, Mann und Frau gemeinsame menschliche Natur, die unser Herr angenommen hat.

Im Hinblick auf die Wahrung der Gemeinschaft in der jeweiligen Kirche und auf die angestrebte Einheit der Kirchen sind bei der Beurteilung dieser Frage nicht nur dogmatisch-theologische Gründe von Bedeutung, sondern auch sogenannte nicht-theologische Faktoren, die das pastorale Handeln der Kirche je an ihrem Ort mitbestimmen. Dies und die Verantwortung jeder Ortskirche für die Gemeinschaft der Kirche muss bei Entscheidungen, die Ortskirchen treffen, mitbedacht werden. ${ }^{25}$

25 U. von Arx, Anastasios Kallis, “"Gemeinsame Überlegungen» der OrthodoxAltkatholischen Konsultation zur Stellung der Frau in der Kirche und zur Frauenordination als ökumenischem Probem" in: Idem (eds.), Bild Christi und Geschlecht in: Internationale Kirchliche Zeitschrift 86 (1996), p. 78-82. For an English translation, see: Idem, "Common Considerations of the Orthodox-Old Catholic Consultation on the Role of Women in the Church and on the Ordination of Women as an Ecumenical Issue" in: Anglican Theological Review 84 (2002), p. 503-506: "In faithfulness to the treasure of tradition, we discern tradition as a process, directed by the Spirit of God, of the dynamic contextualization of the faith for the life and the witness of the Church in its everchanging contemporary situation. This provokes questions concerning the appropriate way of dealing with the tradition (the hermeneutical problem). Thus, we observe that today the Churches justly emphasize the dignity of the laity and especially of women, and that they appreciate the fact that these people occupy an appropriate place in the mission of the Church. This corresponds with the fact that the various tasks in the Church are anchored in their being related to one another as members in the Body of Christ (1 Cor. 12). According to our understanding of tradition as mentioned above, we also investigated the historical data which was brought forward as a rationale for the "male character" of the priesthood: the maleness of the incarnate Son of God, Jesus Christ's choosing of men in the circle of twelve, the exclusive appointment of men to the priestly office of the Church, and the corresponding argumentation with regard to typologies (e.g., Adam-Christ, Eve-Mary), as well as with ideas of the priest being the image or representation of Christ. We have reached the common conclusion that there are no compelling dogmatic-theological reasons for not ordaining women to the priesthood. The soteriological dimension of the Church and its mission is decisive for us: the salvation of humankind and the entire creation in Jesus Christ in whom the new creation is being accomplished. We were especially guided by the conviction that was central to the ancient Church: only that which has been assumed and united with God has been saved. It is human nature, common to men and women, that has been assumed by our Lord. With regard to the preservation of communion in each Church respectively, and to the unity we seek, dogmatictheological arguments - however important they may be - are not of sole importance when dealing with this question. So-called non-theological factors determining the pastoral action of the Churches in each place also play a role. This and the responsibility of each local Church for the communion of the Churches also need to be borne in mind when local Churches are making decisions." 
Thus, the Old Catholic-Orthodox consultation reached its conclusions based on both historical and theological reasoning and finally expressed its conclusions following a theological, specifically soteriological, rationale. For the purposes of the present paper, however, it should be underlined especially that tradition is understood to be dynamic and to have an innovative character, rather than a static or "conservative" one. New questions give rise to revisiting the sources of the faith, both in churches on their own, in the interplay between episkope and synodality, and in dialogue with other churches, both in communion and in great theological proximity. What this entails can be explored further, especially with reference to contemporary developments in the field of intercultural theology as well as with reference to earlier forms of ecumenical thought.

\section{Interculturality and Ecumenism. Intercultural Theology: Sketch of a Paradigm}

Intercultural theology is often presented as a result of the interaction of the fields of missiology, ${ }^{26}$ comparative religion, and ecumenical theology and to a certain extent as its successor, even if the paradigm or perspective that it constitutes, as the "the theological reflection upon the process of interculturation," ${ }^{27}$ is broader than that alone. ${ }^{28}$ Küster, a leading intercultural theologian,

26 The following also appears in Exchange 44 (2015) in the context of a broader contribution on the Mar Thoma Syrian - Old Catholic dialogue.

27 A succinct and apt definition offered by Frans J.S. Wijsen, "Intercultural Theology and the Mission of the Church" in: Exchange 30 (2001), p. 218-228, 221. Thus, rather than a new discipline, intercultural provides a new perspective or method. Its effects can be thorough going, as, e.g., the contribution of Martha Frederiks, Werner Ustorf, "Mission and Missionary Historiography in Intercultural Perspective: Ten Preliminary Statements" in: Exchange 31 (2002), p. 210-218, illustrates: when reading and analyzing the history of Christian missions (or, in fact, of Christianity as such) as the result of a continuous process of interculturation, one achieves a significant different picture than when one would approach it through the lense of one (normative) form of Christianity, for example, that can be seen as being inculturated in or accommodated to different cultures with more or less success. This example from the study of the history of Christian missions illustrates how the intercultural perspective can be valuable both in a heuristic and in an ecumenical sense. Indeed, it can well be argued, as S. Wesley Ariarajah, "Intercultural Hermeneutics - a Promise for the Future?" in: Exchange 34 (2005), p. 89-101, rightly argues that intercultural theology and interculturality as the mode in which theology is being done is nothing new, in fact, it can be seen as being as old as Christianity itself and as having been practiced whenever Christianity came into contact with other cultures. It remains striking, however, that theological dialogues are not frequently, if at all, conceptualized in terms of an intercultural encounter or understood from the perspective of theologizing in the mode of interculturality.

28 See for an palette of topics and fields of study related to intercultural theology, e.g., the contributions collected in: Claude Ozankom, Chibueze Udeani (eds.), Theology in Intercultural Design / Theologie Im Zeichen der Interkulturalität, Amsterdam, 2010. 
writes, for example, the following about its emergence "Important impulses originate in the disciplines of the history of religions or religious studies, missiology and ecumenics". ${ }^{29}$ When Küster considers the heuristic function and potential of intercultural theology, he notes that it can be understood as hermeneutics, comparativistics, and dialogics. The hermeneutical aspects of intercultural theology have to do with the following: "In intercultural hermeneutics one does not primarily seek one's own agenda in the foreign, but respects the other in his difference. One must be able to recognize oneself in the partner's portrayal." ${ }^{30}$ Intercultural theology, however, also moves beyond this and seeks to compare, albeit it with respect for differences, but also with an eye for "transcultural constants." Finally, intercultural theology contains an element of dialogue, such "[i]ntercultural dialogue is understood as the joint search for the truth, which can only be experienced contextually." ${ }^{1}$ The way in which this dialogue takes place is always contextual: "The rules for dialogue for interdenominational, intercultural and interreligious encounters must always be newly negotiated in the process." 32 This latter aspect can be taken as something that is fundamental to Christian theology that takes the notion (and reality) of "interculturality" as, for example, used by Bhabha, and understood to denote a space of absence and difference, ${ }^{33}$ seriously and seeks to move beyond conceptualizations of the relationship between faith and culture in terms of "accommodation" (older missiological paradigms), ${ }^{34}$ inculturation (contextual theological paradigms), ${ }^{35}$ in order to understand, with reference to the notion of "interculturality", processes of interpretation and translation of Christian identities as something belonging fundamentally to Christian theology, which is, as such, is characterized by the revelation of the universal in the particular. The church, therefore, becomes a 'universal hermeneutical community.' ${ }^{36}$

29 See for this and the following: Volker Küster, "Intercultural Theology" in: Religion Past and Present. Brill Online, 2014; accessed 7 June 2014. See also, e.g., the reflections of Martien Brinkman, "Intercultural theology as the Integration of Ecumenism and Missiology" in: J.D. Gort, H. Jansen et al. (eds.), Crossroad Discourses between Christianity and Culture, Amsterdam 2010, p. 579-598.

30 V. Küster, "Intercultural Theology".

31 Ibidem.

32 Ibidem.

33 Judith Gruber, Theologie nach dem Cultural Turn. Interkulturalität als theologische Ressource, Stuttgart 2013, p. 227.

34 Ibidem, p. 17-33

35 Ibidem, p. 34-53.

36 Ibidem, p. 81. See on the notion of translation in relation to theology and culture also and especially: Lamin Sanneh, Translating the Message. The Missionary Impact on Culture, New 
All of this has a close affinity with the work of Robert Schreiter, who, developing a model of theology for a globalized world ("new catholicity"), has also proposed a model of intercultural hermeneutics, or more specifically: intercultural communication, which has four characteristics: first, the observation that meaning is produced by the social judgment of those involved in a (n intercultural) communication event; the judgment involved concerns the interaction of all parties in the creation of meaning. Second, the observation that any such meaning or truth is embedded in the stories or narratives of (living) communities. Third, intercultural hermeneutics aims at finding a balance between differences and sameness, in Schreiter's own words: "Balancing difference and sameness has ethical as well as epistemological significance. Denial of difference can lead to the colonization of a culture and its imagination. Denial of similarities promotes an anomic situation where no dialogue appears possible and only power will prevail." ${ }^{37}$ Fourth and finally, Schreiter's model of intercultural hermeneutics/communication, underlines the role that the agency of all plays: "There can be no passive or inert players in the intercultural communication event, no subjects robbed of their subjectivity." 38 In relation to this, Schreiter also notes that the notion of culture itself is changing; one concept of culture, which is not all that strongly influenced by globalization understands cultures as "patterned systems in which the various elements are coordinated in such a fashion as to create a unified whole. The patterned nature provides a sense of recurrence and sameness that gives to those who participate in the culture a certain identity (the etymological root of which is "same"). The familiarity of the patterns offers a sense of security and of being "at home." ${ }^{39}$ A second notion of culture that is more globalized in nature, or at least takes the dynamics of a globalized world more into account; using insights from postcolonial theory and its understanding of culture as the result of (relational) negotiation and construction along the axes of sameness and difference, comparability and incommensurability, cohesion and dispersion, collaboration and resistance. ${ }^{40}$ When Schreiter brings these (and other) insights in relation to the reconstruction of a catholic theology for a globalized age, he proposes the concept of a new catholicity, which is

York 1989. See also the considerations of Klaus Hock, "Translated Messages? The Construction of Religious Identities as Translatory Process" in: Mission Studies 23 (2006), p. 261-278. 37 Robert Schreiter, The New Catholicity: Theology Between the Global and the Local, New York, 1997, p. 43.

38 Ibidem, p. 43.

39 Ibidem, p. 48-49.

$40 \quad$ Ibidem, p. 54. 
"marked by a wholeness of inclusion and fullness of faith in a pattern of intercultural exchange and communication. To the extent that this catholicity can be realized, it may provide a paradigm for what a universal theology might look like today, able to encompass both sameness and difference, rooted in an orthopraxis, providing teloi for a globalized society." 41

Having thus outlined what intercultural theology is, notably by drawing on two important theorists, without, however, harmonizing them in detail - in line with Küster's observation that, as of yet, there is no one standard understanding of intercultural theology ${ }^{42}$ - with its aspects of hermeneutics, comparativistics, and dialogue, it can also be noted that, while lip service is paid to "interdenominational dialogue", such dialogue, i.e. theological dialogue focusing on matters of faith and order with an eye to the establishment of ecclesial communion across denominational and cultural barriers, is hardly a subject of discussion among those concerned with intercultural theology; rather, emphasis is placed on a more general dialogue between inculturated theologies, ${ }^{43}$ more general topics from the encyclopedia of theology, ${ }^{44}$ or the fundamental dialogical nature of Christian theology. ${ }^{45}$ Conversely, dialogues

41 Ibidem, p. 132-133.

42 See: V. Küster, "Intercultural Theology".

43 See: V. Küster, "Intercultural Theology" as well as his Einführung in die Interkulturelle Theologie, Göttingen 2011, in which hardly any attention is given to theological dialogues and the primary focus seems to be on intercultural theologies as a further development of "contextual" theologies. Also the extensive introduction of Henning Wrogemann, Interkulturelle Theologie und Hermeneutik: Grundfragen, aktuelle Beispiele, Gütersloh 2012, does not pay much attention, if any at all to the field of theological dialogues; this also applies to, for example, Mark J. Cartledge, David Cheetham (eds.), Intercultural Theology: Approaches and Themes, London 2011, and Klaus Hock, Einführung in die interkulturelle Theologie, Darmstadt 2011, see also his "Interkulturelle Theologie - programmatische Assoziationen" in: Interkulturelle Theologie. Zeitschrift für Missionswissenschaft 37 (2011), p. 53-69. This lack of interest in the "faith and order" side of things is doubtlessly explained genealogically, i.e. by a look at the roots of intercultural theology, which have little to do with dialogues of the "faith and order" type. On this, see, e.g., Werner Ustorf, "The Cultural Origins of 'Intercultural Theology" in: Mission Studies 25 (2008), p. 229-251; the divergence between the various fields is also illustrated by the Festchrift in honor of one of the founding fathers of intercultural theology, Walter J. Hollenweger, see: J.A.B. Jongeneel (ed.), Pentecost, Mission and Ecumenism: Essays on Intercultural Theology. Festschrift in Honour of Professor Walter J. Hollenweger, Frankfurt 1992.

44 E.g., christology, see for explorations in this direction, the recent work of Martien Brinkman, The Non-Western Jesus. Jesus as bodhisattva, avatara, guru, prophet, ancestor or healer?, London 2009, and Jesus incognito, Zoetermeer 2011, as well as the earlier work by V. Küster, The Many Faces of Jesus Christ. Intercultural Christology, London 2001.

45 See, e.g., J. Gruber, Theologie nach dem, p. 209-226, on the subject of the canon in relation to the nature of Christian theology. 


\section{of the "faith and order" kind, be they multilateral or bilateral, hardly pay attention to the dynamics of intercultural dialogue and/or theology. ${ }^{46}$ It is}

46 See, e.g., the following recent statements: Commission for Faith and Order, The Nature and Mission of the Church, Geneva, WCC 2005, of which section 61 is of relevance, which notes that "There is a rich diversity of Christian life and witness born out of the diversity of cultural and historical context." Furthermore, the document notes that "The communion of the Church demands the constant interplay of cultural expressions of the Gospel if the riches of the Gospel are to be appreciated for the whole people of God." It also underlines that no culture or cultural expression of Christianity is absolutized. Relevant is also section 69, in which it is noted that "The Church is called upon to proclaim the same faith in each generation, in each and every place. Each church in its place is challenged in the power of the Holy Spirit to make that faith relevant and alive in its particular cultural, social, political and religious context." See also: Commission for Faith and Order, The Church: Towards a Common Vision, WCC Geneva, 2013, section 6 of which notes that "One challenge for the Church has been how to proclaim the Gospel of Christ in a way that awakens a response in the different contexts, languages and cultures of the people who hear that proclamation... [The resulting] diversity within the unity of the one Christian community was understood by some early writers as an expression of the beauty which Scripture attributes to the bride of Christ." Furthermore, section 28 states that "Cultural and historical factors contribute to the rich diversity within the Church. The Gospel needs to be proclaimed in languages, symbols and images that are relevant to particular times and contexts so as to be lived authentically in each time and place. Legitimate diversity is compromised whenever Christians consider their own cultural expressions of the Gospel as the only authentic ones, to be imposed upon Christians of other cultures." Thus, even though processes are described that could be analysed and further clarified from the perspective of interculturality or intercultural theology, this does not take place. Even the word "intercultural" is absent from these documents. This is a somewhat surprising development, taking into account that the notion was very much on the forefront of a 1995 WCC consultation. See: "On Intercultural Hermeneutics. Report of a WCC Consultation. Jerusalem 5-12 December 1995” in: International Review of Mission 85 (1996), p. 241-252, while it also still figured in Commission on Faith and Order, A Treasure in Earthen Vessels, Geneva WCC, section 44 (albeit in an interpretation that comes close to a notion of "contextual theology"). A similar picture emergence when looking at recent bilateral dialogue that produced major reports, e.g. the Roman Catholic Old Catholic dialogue in its report The Church and Ecclesial Communion, 2009. See: http:// www.vatican.va/roman_curia/pontifical_councils/chrstuni/vetero-cattolici/rc_pc_chrstuni_ doc_20090512_report-church-ecclesial-communion_en.html, accessed June 7, 2014, which notes in it section 20 about the ministry "It is part of their mission to give expression to and preserve the unity of the church and its maintenance in the one truth in a constant process of world-wide mission and inculturation of the gospel." In relation to the ordination of women to the apostolic ministry in the Old Catholic Churches, the document then notes on p. 70: "In view of the cultural transformation which has among other things brought about a situation in which women now in every respect assume the same leadership responsibilities as men, they believe that they owe it to the gospel and the transmission of the faith to take the corresponding step - just as the church in earlier times again and again believed it could recognize the kairos for a responsible inculturation of the message of Christ to which it above all wishes to be faithful.". Again, inculturation plays a role, expressions are used that could be interpreted in the sense of theology in the mode of interculturality, but the concept itself is absent. This also applies to the many bilateral dialogues of the Anglican communion (on which see: P.-B. Smit, Tradition in Dialogue. The Concept of Tradition in International Anglican 
precisely at this interface, however, that this contribution is located. Why this is the case will be now outlined briefly.

Many, if not most theological dialogues between churches take place either between churches that are part of the same or of a similar cultural context, or, in the case of dialogues between confessional families, the commissions will be mixed, such as to provide sufficient overlap between representatives from different cultural contexts; discussions within world Christian communities, such as the Anglican Communion and others are, strictly speaking, not ecumenical dialogues and have their own dynamic. This also applies to discussions revolving around matters of Life and Work. The dialogue between the Mar Thoma Syrian Church and the Old Catholic Churches of the Union of Utrecht differs from many of such dialogues in that it was a dialogue that took place between members of a commission that did not share each other's culture; at most, the senior Mar Thoma delegates had had significant exposure to Western culture because of their ministries and education. What took place in terms of dynamics, however, can be described as follows, when reading it informed by the theorization of Küster and Schreiter and taking into account the notion of interculturality as an important aspect of the development of theology.

Bilateral Dialogues, AMSTAR 3, Amsterdam 2012, see, e.g., "International Commission for Anglican - Orthodox Theological Dialogue" in: The Church of the Triune God, London 2006, p. 29-32, which does discuss the (missiological) notion of inculturation and the need for mutual accountability when inculturating the Gospel, but not the notion of interculturality. - In fact, inculturation is, in all of these dialogues, seen as a necessity, the resulting diversity both as a treasure and as a threat to the unity of the churches and continuity of the faith, absolutizing one culture is rejected, while incidentally (e.g., the ordination of women in the Roman Catholic - Old Catholic dialogue) processes are described that could be understood as expressions of theology in the mode of interculturality, but the notion and perspective are both absent from these texts.

Probably even more strikingly, though, also recent missiological documents from the WCC do not use the notion of interculturality. For example, in the 2012 document Together Towards Life: Mission and Evangelism in Changing Landscapes, prepared by the WCC's Commission on World Mission and Evangelism, see: http://www.oikoumene.org/en/resources/ documents/wcc-commissions/mission-and-evangelism/together-towards-life-mission-andevangelism-in-changing-landscapes, accessed June 11, 2014, it is noted in its section 100 that "A plurality of cultures is a gift of the Spirit to deepen our understanding of our faith and one another. As such, intercultural communities of faith, where diverse cultural communities worship together, is one way in which cultures can engage one another authentically and where culture can enrich gospel." Some guidelines for this authentic engagement are outlined subsequently, but none of these betrays an in-depth engagement with the insights of intercultural theology, even if the remark about engaging each other and thus enriching the gospel might be seen as pointing into a compatible direction. To be sure, the same applies to another major missiological statement of recent vintage: Pope Francis' apostolic exhortation Evangelium Gaudii (2013). 


\section{Faith and Order goes Intercultural? The Dynamics of the Mar Thoma Syrian - Old Catholic Dialogue from the Perspective of Intercultural Theology}

As was just indicated, here, it will be attempted to bring together the dynamics, method, and content of the Mar Thoma Syrian - Old Catholic dialogue and an intercultural approach to/perspective on, (ecumenical) theology with the aim of further demonstrating what tradition and renewal in an Old Catholic theological paradigm amount to. In doing so, the hermeneutics of Küster and Schreiter, enriched by insights from Gruber and others, which provide a representative, even if not a full, picture of what theology from the perspective of interculturality and its appertaining forms of hermeneutics and communication amount to, will be used as a lens for reading the dialogue from the perspective of intercultural theology; having attempted this, it will also be asked whether viewing ecumenical dialogues of the "Faith and Order" type from the perspective of intercultural theology offers any new input for the latter paradigm itself. At the same time, it may be noted that, by interpreting the dialogue from an intercultural perspective, this paper adds to the consideration of "inculturation" and especially theology in the mode of "interculturation" in Mar Thoma Syrian and Old Catholic tradition, given that there the notion of "inculturation" is used frequently, but the notion of "interculturation", in the sense described above, is only beginning to be employed. ${ }^{47}$ Having stated this, it is now possible to attempt the intercultural interpretation of the Mar Thoma Syrian - Old Catholic dialogue.

First, it proved to be of high importance in the dialogue to engage in a careful process of listening, asking question, revising one's pre-understandings, and searching carefully for the importance of particular words and concepts in the discourse and tradition of oneself and the other. At some point in the dialogue, originally somewhat jokingly, the image of a "Mar Thoma - Old Catholic/Old Catholic - Mar Thoma" dictionary began to be used, as an illustration of the necessity of this process. An example of misunderstanding and their resolution was, at a micro level a long discussion about the word "synod", which, in the Mar Thoma Syrian tradition refers to a meeting of bishops (in Old Catholic terminology: a conference of bishops, such as

\footnotetext{
47 See for representative positions, e.g., Alex Thoma, A History of the First Cross-cultural Mission of the Mar Thoma Church, 1910-2000, Delhi 2007, and Joris Vercammen, "Bauen an der «neuen Katholizität». Der ökumenische Auftrag der Utrechter Union“ in: Internationale Kirchliche Zeitschrift 98 (2008), p. 73-96. See for an important input into the Old Catholic discourse also: Anton Houtepen, "Oikumene oder der Weg zu einer neuen Katholizität" in: Internationale Kirchliche Zeitschrift 96 (2006) p. 9-42.
} 
the IBC), and in Old Catholic terminology would refer to a body notably including laity, priests, and deacons as well. (in Mar Thoma terminology, the Prathinithi Mandalam or "Legislative Assembly"); in the end, the formulation "structures of church governance that are characterized by episcopal leadership and structures that assure the participation of laity and clergy alike in processes of discernment and decision making" ${ }^{48}$ was used. On a macro-level, a similar process took place in relation to, for example, Christology and the commemoration of the faithful departed. The hermeneutical process that took place here, seems to be that what Küster describes with the notion of "hermeneutics", i.e. the search for an understanding of the other in which difference is not negated, but in which the other can recognize him- or herself. ${ }^{49}$ At the same time, it is clear, as Schreiter says, that the embeddedness of meaning (of a word like "synod") or truth (e.g., of certain Christological notions) is embedded in the narratives of living communities, while it was a precondition for achieving mutual understanding, not yet to speak of agreement, that both parties were actively engaged in the sometimes heated discussions, which is fully in line with Schreiter's emphasis on the need for the agency of all in the process of intercultural hermeneutics/communication.

This process of understanding each other in a way that was also recognizable for the one that was understood was greatly aided by the face-to-face meetings of the commission (a requirement it noted at its first meeting, stating that "Personal meetings of a joint commission are indispensable in order to enhance mutual trust and clarify open questions." $)^{50}$ This, of course, aided a nuanced discussion, but, just as importantly, it allowed the participants to share in each other's lives, at least to a certain extent, which, just as the participation in each other's liturgies and prayers allowed the participants in the discussions to discover the context and meaning of words and concepts that the other used, i.e. the meaning of words and concepts became clear through the discovery of their rootedness in a lived tradition and the (at least partial) participation in this tradition. Besides an important element of "sameness" that could be discovered in this way, the convivencia that was experienced in this way also led to trust, ${ }^{51}$ which again enhanced the process of intercultural understanding. ${ }^{52}$ All of this

\footnotetext{
48 "Santhigiri Statement, 1.1" in: Internationale Kirchliche Zeitschrift, 102 (2012).

49 V. Küster, "Intercultural Theology".

50 "Santhigiri Statement, 3" in: Internationale Kirchliche Zeitschrift, 102 (2012).

51 See: Rudolf von Sinner, "Trust and Convivencia. Contributions to a Hermeneutics of Trust in Communal Interaction" in: The Ecumenical Review 57 (2005), p. 322-341.

52 See on all of this the pointed and apt contribution of Jim Harries, "Intercultural Dialogue

- An Overrated Means of Acquiring Understanding Examined in the Context of Christian
} 
also greatly aided the process of comparison, which will be turned to next, and during which mutual trust was essential when it came to sketching, or rather: rewriting, the position of the other in a way that was both recognizable for the other and understandable for oneself, as well as vice versa..$^{53}$

Second, the dialogue contained a strong element of comparison, which was, to be sure, facilitated by an understanding of the tradition and position of the other. In fact, the comparison took place, to a large extent, through a process of describing and discussing the positions of both churches on any given subject prior to attempting to formulate a joint position in language that did both justice to one of the two churches' position on a topic in its own eyes and did not lead to misunderstandings - and could, therefore, serve as the basis for a real comparison - in the eyes of the other church (see, e.g., the example of the notion of "synod" above). This way of operating also left substantial space for the articulation of the differences in the two traditions and, especially, for the different journeys through history that the two churches had behind them. Again, the recognition that any meaning or truth is embedded in a community's narrative, the active participation of all in the conversation, the recognition and formulation of differences, with keeping an open eye for similarities and sameness, all important aspects of both Schreiter's intercultural hermeneutics as such and of Küster's notion of both hermeneutics and comparativistics were of high importance for this process, even if they were not named as such at the time.

Third and finally, all the hermeneutics and comparativistics involved in the dialogue stood in the service of a "joint search for the truth." ${ }^{44}$ In actual practice, this consisted of (and is reflected as such in the statements of the dialogue) the formulation of a common position on a variety of subjects. This required both a language and conceptuality that both agreed on and understood in a sufficiently similar way and an understanding of both traditions, based on a process of comparing them to each other in an atmosphere of trust, that all could identity with and understand in (at least largely) the same way. The formulation of the "truth", both about the two traditions involved and from a rootedness within these traditions (see Schreiter's emphasis on the embeddedness of meaning in living traditions), involved the "social judgment” (Schreiter) of all involved (see Schreiter's emphasis on agency), the

\footnotetext{
Mission to Africa” in: Exchange 37 (2008), p. 174-189.

53 As the main drafter of the joint statements (or, less glamorously: the de facto secretary of the dialogue), the physical and mental experience of "rewriting" the own faith was a particularly rewarding one for the author.

54 V. Küster, "Intercultural Theology".
} 
acknowledgment of differences as well as that of sameness. What it amounted to in the end was a sketch that formulated a consensus about the convergence (and divergence) of the two traditions in such a way that the two particular traditions were both able to recognize themselves in it and to recognize in the joint formulation that the other shared ("essentially") the same faith, thus, by reformulating and rewriting the own tradition in a joint statement, transcending the boundaries (in terms of conceptuality, etc.) of the own particular tradition in a process of the joint traditioning of the faith together with the other, and, in that sense, discovering both the catholicity, in the sense of the plenitude, of the faith of the other and that oneself in a new way.

In particular the third and last point can give rise to further reflection. What is described there is nothing else but the rediscovery of the Christian faith for, in this case, both parties involved, in a way that allows them to remain rooted in their own traditions with all their differences and at the same time rediscover the meaning and value of this very particular tradition by restating it together with another party, or, rather, in the encounter with another tradition, another product of the ever-ongoing process of the development of Christian identities and theologies in the mode of interculturation. The continuation of this process of rewriting and reperforming one's tradition and identity, but with a difference, ${ }^{55}$ or of the translation of the own tradition and identity into a "language" that can be understood both by oneself and the other without any (too serious) misunderstandings is both triggered and facilitated by the encounter with the other. In this way, to borrow a term from De Wit, ${ }^{56}$ the other provides an "epiphanic space", in which the other, because of his/her otherness offers the opportunity, by means of the encounter with the other, to rediscover oneself in the process of rearticulating and rewriting oneself, or one's own tradition in relation to the other, which means addressing questions asked because of the otherness of the other and, in order to address these questions,

55 See for this, from the perspective of ecumenism beyond the cultural turn: Claudia Jahnel, "Vernacular Ecumenism and Transcultural Unity. Rethinking Ecumenical Theology after the Cultural Turn" in: Ecumenical Review 60 (2009), p. 404-425, Jahnel goes a long way in reframing ecumenical theology in an intercultural way, but still does not tie this directly to the experience of bilateral dialogues; for the notion of reperforming with a difference, see also: Judith Butler, Gender Trouble, London 1990, and queer studies in general, the implied eschatological character of interpretation/rewriting and performance is also articulated by Hans de Wit (inaugural lecture), see: J.H. de Wit, My God', She Said. 'Ships Make Me so Crazy,' Reflections on Empirical Hermeneutics, Interculturality and Holy Scripture, Amsterdam 2008, p. 27-30.

56 See, e.g., J. H. De Wit, My God', She Said., p. 65, 87; the term seems to suffer from some underdefinition in the De Wit's work; its current use seeks to employ it in line with the overarching interests of De Wit's project of reading the Bible "through the eyes of another." 
a rethinking and resourcing of one's own tradition, which, paradoxically, can lead to a new revelation of oneself to oneself (in the sense of: one's identity to oneself) because of the encounter with the other who opens up the revelatory space for this. Thus, the encounter with the other is an important, if not the most important catalyst for the ongoing process of interculturation which is the mode in which Christian identity - just like any other identity - exists. It agrees well, to be sure, with a dynamic view of tradition, as it has been developed and become current in the tradition of Faith and Order within the ecumenical movement, as the following excursus will demonstrate.

\section{Excursus: Viewing the Mar Thoma Syrian - Old Catholic Dialogue Through the Lens of Montreal 1963}

By way of excursus, the entire process of the dialogue and its outcome as they are discussed here can also be described following the logic and lines of thought of the well-known and well-established formulations of the 1963 Fourth World Conference on Faith and Order of Montreal, which can, by that route, also be related to an intercultural perspective on theology.

With an eye to transcending discussions concerning the relationship between Scripture and tradition and providing a paradigm for the consideration of the interrelationship of various kinds of traditions, thus offering a matrix for the conceptualization of the relationship between one's own particular tradition and "Tradition", Christ's presence in the life of the Church, and the appreciation of the process of traditioning. In the conference's report, the main statements on this matter of the 1963 Montreal conference run as follows:

By the Tradition is meant the Gospel itself, transmitted from generation to generation in and by the Church, Christ Himself present in the life of the Church. By tradition is meant the traditionary process. The term traditions is used...to indicate both the diversity of forms of expression and also what we call confessional traditions, for instance the Lutheran tradition or the Reformed tradition...the word appears in a further sense, when we speak of cultural traditions. (Section II, par. 39.)

Our starting point is that we as Christians are all living in a tradition which goes back to our Lord and has its roots in the Old Testament and are all indebted to that tradition inasmuch as we have received the revealed truth, the Gospel, through its being transmitted from one generation to another. Thus we can say that we exist as Christians by the Tradition of the Gospel (the paradosis of the kerygma) testified in Scripture, transmitted in and by the Church, through the power of the Holy Spirit. (Section II, par. 45.)

The traditions in Christian history are distinct from, and yet connected with, the Tradition. They are the expressions and manifestations in diverse 
historical forms of the one truth and reality which is Christ. This evaluation of the traditions poses serious problems .... How can we distinguish between traditions embodying the true Tradition and merely human traditions? (Section II, par. 47 and 48. $)^{57}$

When considering the Mar Thoma Syrian - Old Catholic dialogue through the lens of the matrix offered by the Montreal conference, a number of observations can be made.

First, the starting point of the members of the dialogue commission was, inevitably, a particular tradition, albeit with an eye to recognizing its essence in the tradition of the other, understanding (at least) the particular tradition as one of multiple valid "expressions and manifestations in diverse historical terms of the one truth and reality which is Christ." The question was whether it would be possible to recognize the essence of the particular faith tradition in that of the other and to formulate this in terms of a shared faith as well.

Second, the goal of the dialogue, or at least the hoped for result, was the discovery of the presence of the Gospel in an identical way, i.e. in a way in which both churches could recognize the essence of their own faith, which is none other than the Gospel (as defined by Montreal 1963, Christ's presence in the life of the Church, or "Tradition") or its own catholicity. ${ }^{58}$ This Gospel cannot be made or created, but only discovered. The road towards such a (potential) discovery is connected to Montreal's second understanding of tradition.

Third, the process of intercultural encounter and the ensuing rewriting of the faith, including its rediscovery as such and its discovery in the tradition of the dialogue partner, leading to its joint formulation, can well be understood as a part of the process of traditioning, which is the second kind of tradition that the Montreal conference distinguished, acknowledging that "we exist as Christians by the Tradition of the Gospel (the paradosis of the kerygma) testified in Scripture, transmitted in and by the Church, through the power of the Holy Spirit." The intercultural process of the joint formulation and hence rewriting of the faith as it took place during the dialogue is, in fact, a manifestation of the transmission of the faith in a new way.

Thus, what was described above along the lines of the paradigm of intercultural theology can, in fact, also well be understood and described along

57 Text in Günther Gassmann (ed.), Documentary History of Faith and Order 1963-1993, Geneva, WCC 1993, p. 10-18. See also P.-B. Smit, Tradition in Dialogue, p. 43-55.

58 Understood in the qualitative sense of the word, i.e. as the participation "in the whole reality of salvation and truth that comprises God and humans, heaven and earth". Preamble to the Statute of the International Old Catholic Bishops' Conference, 3.2, see: U. von Arx, Maja Weyermann (eds.), Statut der Internationalen Altkatholischen Bischofskonferenz (IBK). Offizielle Ausgabe in fünf Sprachen, Beiheft Internationale Kirchliche Zeitschrift 91, Bern 2001; on this understanding of catholicity, see U. von Arx, "Was macht die“. 
the lines of the paradigm of the 1963 Montreal conference. This observation is useful, given that it indicates continuity between the two paradigms and sheds additional light on the dynamics of the dialogue considered in this contribution. Furthermore, what Montreal describes in terms of the process of traditioning in which the "universal" (Tradition) is present in the "particular" (traditions) in ever new ways through a continuing process of negotiating, rewriting, reconstructing this presence in the intercultural space, characterized by the encounter with the "other", can well be understood as the dynamics of intercultural encounter and dialogue. Traditioning, in fact, can be understood as another word for negotiating interculturality, or, rather: for doing theology in the mode of interculturality.

\section{Reflection on an Intercultural Analysis of an Ecumenical Dialogue}

The above considerations, reflection on the Mar Thoma Syrian - Old Catholic dialogue lead to perspectives on ecumenical dialogue and understanding that offer vistas that go well beyond this particular dialogue. They include the following.

First, it has become clear that, despite the fact that intercultural theology has, so far, paid scant attention to the dynamics of theological dialogues of the type studied here, while such dialogues themselves hardly operate with the notion of interculturality, such dialogues and their dynamics can very well be interpreted from an intercultural perspective and appear as instances of doing theology interculturally. Even a "traditional" paradigm for conceptualizing such dialogue, i.e., that of Montreal 1963, appeared to be capable of being reinterpreted along intercultural lines. The various aspects and characteristics of (good) intercultural hermeneutics and dialogue as described by intercultural theologians such as Schreiter and Küster were very much present in the dialogue analysed here. In the same dialogue also the importance of convivencia, was very apparent, as well as the dynamic of, in the epiphanic space provided by the encounter with the other, in order to enable the dialogical rewriting and rediscovering of one's own tradition in such a way that the result was both faithful to this tradition and understandable for those rooted in another tradition. Contextuality and transcontextuality, therefore, went hand in hand in this dialogue. This, indeed, leads to rediscovering of the quality (fullness, catholicity) of one's own tradition in that of the other and vice versa, which, with Schreiter, can be conceptualized as a new catholicity, or with the statute of the Old Catholic International Bishops' Conference as catholicity as such. ${ }^{59}$

59 See: Preamble to the Statute of the International Old Catholic Bishops' Conference, 3.2 in: U. von Arx, M. Weyermann (eds.), Statut der internationalen. 
Second, given that this is the case, the current contribution also leads to the conclusion that there exists a considerable challenge, both for mainstream models of intercultural theology and for theological dialogues as studied here. Given that theological dialogues can be fruitfully understood as expressions of intercultural theology, the field of intercultural theology could consider why it is that these dialogues are so seldom seen as expression of theology in the mode of interculturality and so little used as a source of intercultural theology. Can reflection on these dialogues contribute anything to an understanding of the dynamics of intercultural theology? Vice versa, those involved in theological dialogues or any process of consensus-seeking theology of the "Faith and Order"-tradition, could consider whether a fuller integration of the notion of interculturality might not be beneficial, both for the understanding of the dynamics of the traditioning of the Christian faith as such and for the understanding of such dialogues themselves.

\section{General Conclusions: Renewal in Old Catholic Theology}

On the basis of the above, what can be concluded about the characteristics of ecclesial and (therefore) theological renewal within the Old Catholic tradition? First, it can be easily substantiated, given the preceding considerations, that the process of traditioning within a particular tradition and focused on the content of all Tradition, Christ's presence in the Church, is an apt description of the process of theological renewal within Old Catholicism. From the inception of the Old Catholic movement onwards, as well as in earlier traditions, such as that of the Church of Utrecht, ${ }^{60}$ a return to the sources as a way of ecclesial renewal was of paramount importance. Second, this return was made a necessity for two reasons: 1) ecclesial developments, be they schism or ecumenical rapprochement; 2) societal developments, prompting the Church to rethink its articulation of tradition. The "challenge of the other" was and is, therefore, of the utmost importance for ecclesial renewal within Old Catholicism. Third, the process of renewal is one that involves dialogue and the participation of all the faithful (one could compare this to an actuosa participatio in processes of decision making concerning matters of discipline and doctrine - or one could call it synodality). This makes for a slow process, but it also ensures that the renewal of the Church has a basis in the people of God and not "just" in the ecclesial hierarchy; such dialogue also always involves dialogue with ecclesial partners. Renewal can only be true renewal if it is ecclesial and ecumenical in nature, in other words: catholic renewal.

60 See: D. J. Schoon, Van bisschoppelijke Cleresie. 